\title{
13. Sorcery- and Witchcraft-Related Killings in Papua New Guinea: The Criminal Justice System Response
}

\author{
Ravunamu Auka, Barbara Gore and Pealiwan Rebecca Koralyo
}

\section{Introduction}

The Office of the Public Prosecutor (OPP) in Papua New Guinea (PNG) is empowered by the constitution to undertake the prosecution function of the state in the National Court and in the Supreme Court of PNG. The prosecutors of the OPP are therefore responsible for the conduct of trials in the National Court and the defending of appeals in the Supreme Court. This role places the prosecutors in a position of responsibility for securing justice for both victims and persons accused of sorcery and for victims of sorcery-related killings. Most often victims of sorcery-related killings are persons accused or held in suspicion of practising sorcery.

This paper will outline the historical and more recent responses by the criminal justice system to sorcery- and witchcraft-related killings. Furthermore, through analysis of case studies an observable trend in the increasing number and increasing levels of violence in sorcery- and witchcraft-related killings in PNG will be discussed. Finally, we will discuss the perspectives from the prosecutors of the OPP on the future role of the criminal justice system in responding to sorcery- and witchcraft-related killings.

\section{Sorcery in Papua New Guinea}

The overwhelming majority of Papua New Guineans, regardless of age and gender, believe in the existence of sorcery. PNG is a diverse country comprising more than 800 ethnic groups; all have a system of beliefs that accounts for sorcery and its existence. Sorcery is believed by many as being part of PNG's unique and noble culture and a sacred tradition that is observed in many different ways by the different ethnic groups (Gibbs 2009; Oxfam 2010; Rangan 2009). 
The courts have recognised this widespread belief in sorcery in PNG, as expressed by the late chief justice Sir Buri Kidu:

There is no doubt that in this country the belief in sorcery is widespread and nobody really has to prove to the court that it exists. Belief in sorcery exists amongst some of the most backward of our people in the mountains of every province and also in the urban areas, including Port Moresby. Very well-educated people believe that sorcery exists and that there is power in people who practice evil sorcery to cause the death of other persons. ${ }^{1}$

The preamble to the constitution recognises Papua New Guinean ways under National Goal 5. This includes the recognition of cultural practices and rituals experienced in our communities and daily lives. Although there are customary rules that regulate the communities and separate ethnic groups, the constitution enables and empowers other legislation and creates law-making and law enforcement agencies to govern and maintain law and order in society. Acts of sorcery have been governed by separate legislation, but other laws in this country are also observed to maintain fairness and peace in societies, communities and the country as a whole.

\section{The law}

\section{Sorcery Act 1971}

The national parliament recently passed legislation to repeal the Sorcery Act 1971, and this has already taken effect. The Act made sorcery an offence, with the Act defining and recognising sorcery and the belief in sorcery that exists in PNG. Sorcery is defined in the Act (Section 1) as:

'sorcery' includes (without limiting the generality of that expression) what is known in various languages and parts of the country as witchcraft, magic, enchantment, puripuri, muramuradikana, vada, meamea, sanguma, or malira, whether or not connected with or related to the supernatural.

Sorcery itself as an offence was very difficult to prove in any court of law. This is largely because in order for one to answer to such an offence there must be evidence demonstrating that sorcery was practised by that person. Almost always the evidence in such cases is lacking because sorcery is a sacred practice

1 State v. Aiaka Karavea \& Anor [1983] N452(M) (20 September 1983). 
and no one wants to talk openly about it. Additionally, no physical or tangible evidence can be brought before the court because with sorcery everything involves the use of supernatural powers or a supernatural being. Even when witnesses can be brought in, their accounts can be illogical, improbable, and of rather impossible events, making it impossible to prove in court. Having said that, it strengthens the notion that sorcery is something associated with the supernatural, and the belief that it exists. It must be emphasised that the Sorcery Act itself, or indeed the belief in sorcery, does not, nor did not, in any way prevent law enforcement and prosecution in the area of sorcery-related killings or violence.

\section{The Criminal Code}

The Criminal Code Act is the legislation that prescribes the most serious of criminal offences in PNG. One of the primary functions of the OPP is to uphold and to enforce the Criminal Code in terms of attending to and representing the state in criminal trials in the National Court and appeals in the Supreme Court. The Criminal Code does not specifically prescribe sorcery as a crime; this offence was prescribed under the Sorcery Act. However, the Criminal Code does provide for offences that amount to sorcery- or witchcraft-related violence. Most often the charges laid against persons for killing suspected sorcerers are that of wilful murder or murder. The difference between these two offences is that a person charged with wilful murder, which involves an element of intention to kill, is liable to the death penalty, whereas a person charged with murder is liable to life imprisonment. The role of OPP prosecutors is to present evidence in court against persons charged with killing a suspected or known sorcerer, and to have the person charged with that offence and be dealt with according to the law by the courts in their administration of justice.

Often, persons charged with killing a suspected or known sorcerer have indicated that their reasons for killing that person was because of the deceased's practice of sorcery killing or causing illness to a close member of their family or their friends. Bearing in mind PNG's culture and traditions, prosecutors and courts have recognised the belief in sorcery and have conceded to it being a mitigating factor in sentencing. The Supreme Court of PNG has taken the belief of sorcery and the violence that results thereof into account in one its judgments:

The belief in sorcery taken together with other factors in their favour only operates to reduce a life sentence to a term of years. It does not and should not operate to render a sentence equivalent to that usually imposed by judges here for murder, manslaughter, dangerous driving causing death, infanticide. ${ }^{2}$

2 Agoara Kelo \& Anor v. State (1981) SC198. 
This had become precedence and the practice in the PNG criminal justice system in its approach to sorcery-related killings. In recent times this view has changed and sorcery or the belief in it is now held to be an aggravating factor when determining a sentence.

\section{Sorcery-related violence cases in the Papua New Guinea courts}

\section{Formal legal system process}

The number of cases relating to sorcery- and witchcraft-related violence that come to the National Court of Justice in PNG is not as many as it should be. The figures are inaccurate and do not reflect the number of acts actually occurring. This is evidenced by the numerous reports in the media; however, only a few cases of sorcery-related violence have come to court and even fewer cases of a person being accused of being a sorcerer have come to court. The only reported case of a person being convicted of sorcery was in 2008 when a man was charged under the Sorcery Act for threatening another that he would use sorcery on that person. The National Court sentenced that man for only a year. This was for the threat of using sorcery. ${ }^{3}$

Sorcery-related violence can be prosecuted in our courts under charges of murder or wilful murder, grievous bodily harm, or even as unlawful assaults. Prosecutors do not determine the number of cases that come to the National Court, but it is all part of the criminal justice process. The process begins when an aggrieved person lays a complaint with the police; the police then investigate and if there is sufficient evidence they will arrest the perpetrator or perpetrators and charge them accordingly.

The matter then goes through the committal process in the district court; the equivalent of the district court here is the magistrates court. This court determines whether there is enough evidence for the offenders to stand trial in the National Court. If there is, the matter comes to the OPP.

Criminal matters before the National Court can proceed by way of a trial or a plea of guilty. In the instance of a trial the prosecutors acting for the state present all the evidence the state has against the alleged offender or offenders. This evidence is what was collected by the police in the initial investigation, and any other evidence that the prosecutor considers relevant and admissible.

3 State v. Parara [2008] PGNC 259; N3957 (22 February 2008). 
After all the evidence is put before the court the offender represented by their counsel can make their defence. Counsel may present evidence in the court that the alleged offender was not the person who committed the act of violence against the known or suspected sorcerer. Then the court decides whether the offender is guilty or not. If the court finds that he is not guilty then the court will acquit him or her of the charges, but if the court finds the offender guilty and convicts then the court decides the penalty.

This penalty is the sentence the court gives and the offender is to serve this in custody or sometimes it can be partially suspended depending on certain factors such as age or medical condition. The penalties given to an offender vary according to aggravating or mitigating factors. The aggravating factors refer to those facts in the case that make the sorcery-related act of violence heinous and more serious, whereas mitigating factors are those considerations that make the act of violence one that can be looked at less harshly, given that certain facts such as expression of genuine remorse, the offender is young or has pleaded guilty. Other considerations like medical reports are also taken into account because these reports are independent expert opinions that indicate the weapons used and the extent of the injuries inflicted to determine the degree of aggravation. These matters are placed before the court in submissions made by both the prosecutor and the defence counsel. The court then in their discretion and administration of justice determines the sentence to be imposed.

\section{Court data and analysis}

We now analyse data collected from 26 reported National Court judgments taken from the Pacific Islands Legal Information Institute databases (PacLII), ${ }^{4}$ in order to gain a perspective of the way in which sorcery- and witchcraft-related violence has been dealt with by the National Court of PNG. The statistical analysis that follows is not comprehensive but does provide an indication of what is before the courts and what the criminal court response has been to sorcery-related killings. It is noted that most cases of sorcery-related violence in the National Court end up as a plea of guilty, with only the sentence to be decided by the National Court.

It is common knowledge that there are many cases in the country of sorceryrelated violence as reflected in the media or tales heard in our communities; however, in 32 years, from 1980 to 2012, the number of cases reported on PacLII was only 25 (see list at the end of the chapter). 


\section{Charges and sentences of sorcery-related violence}

A person is usually charged with wilful murder or murder in relation to the death of a victim who is often accused of being a sorcerer. Upon conviction this person is liable to death, life imprisonment or imprisonment of more than 25 years. The ultimate discretion lies with the presiding judge, who takes into account the circumstances of the case with the law to award the appropriate sentence. From 1980 to 2012, nine charges of wilful murder were made, and 10 charges of murder. The sentences for these charges are summarised in Figure 1.

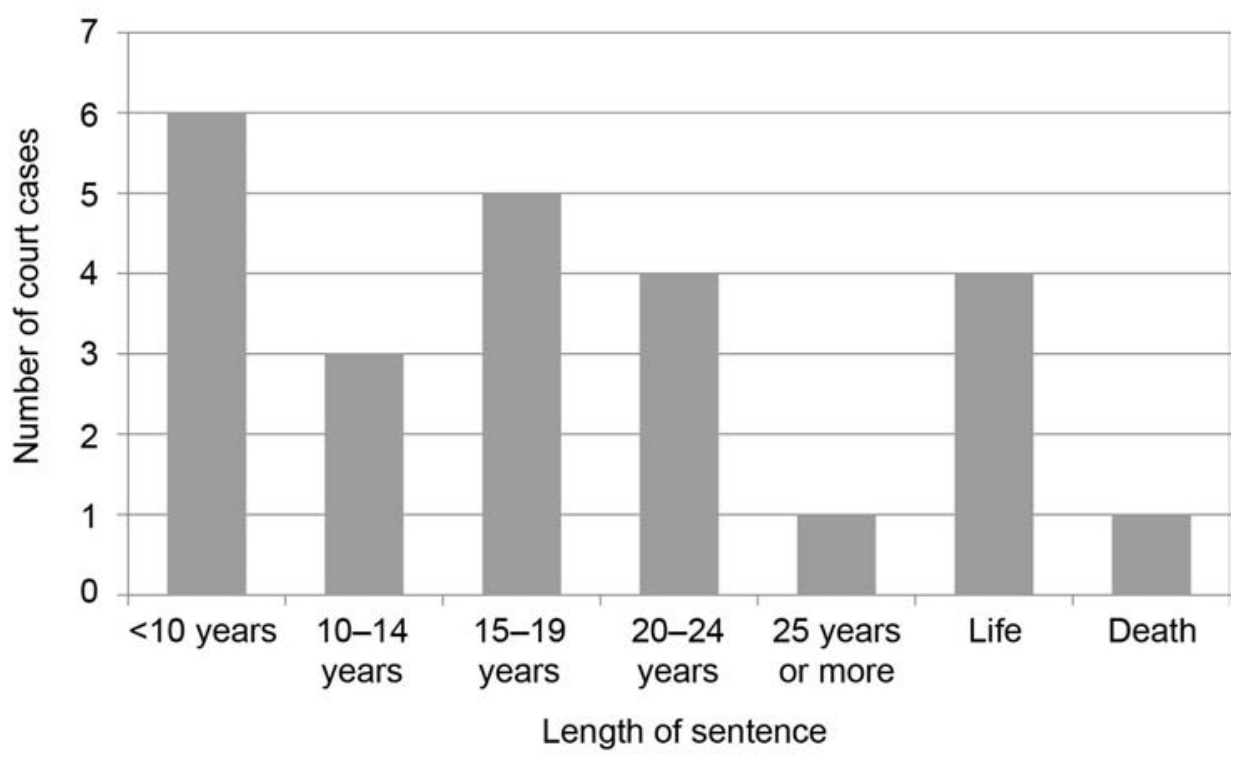

Figure 1: Sentences handed down in relation to the commission of sorcery-related violence offences, 1980-2012.

Source: Pacific Islands Legal Information Institute databases (www.paclii.org).

The most observable trend to note is that a person responsible for killing a known or suspected sorcerer will be charged with wilful murder or murder. The courts had earlier adapted to culture and traditions and saw sorcery as a major mitigating factor in sentencing. However, in recent times this view has changed and the courts are imposing harsher penalties on persons responsible for killing another person regardless of whether the victim was a known or suspected sorcerer.

For instance, in 2007 two people were sentenced to death, showing the serious approach taken by the courts in relation to sorcery-related violence. This can be contrasted with a case in 1980 where a sentence of six years was deemed 
appropriate given that sorcery-related killing was a special category of its own, meriting a lesser sentence than all other kinds of wilful murder offences that would normally attract a sentence of many years up to a maximum of life imprisonment. ${ }^{5}$

The case in 2007 was far more serious than the case in 1980. In his judgment the trial judge accepted that belief in the power of sorcery is common in many communities in PNG today and is a mitigating factor. However, it was his view that with the introduction of Christianity, western civilisation, and the establishment of government administration and authorities the courts should not continue to treat belief in sorcery as a bar to imposing the maximum penalty in a serious wilful murder case. The judge stressed that each case is different and the imposition of the death penalty depended on the factual circumstance of the case.$^{6}$ Therefore, in the 2007 case, a harsher penalty of death was warranted. This is an indication that the PNG courts will not tolerate sorcery-related violence. It is notable that after 2000 there have been more reported cases of sorcery-related violence and the sentences imposed by the courts have been harsher than in the 1990s, regardless of whether or not there is a plea of guilty.

\section{Offenders and victims of sorcery-related violence}

It is not often that a deed or offence is committed by an individual. From the 26 National Court cases examined, only 20 cases reported charges being laid for violence relating to sorcery, and of these 20 cases eight offences were committed by individuals and 12 offences were committed by groups. Most indications are that these offenders have a strong belief that the person they are killing is a sorcerer and it is in the common good of all that persons should take action to rid the community of this one person than to wait and see other people die.

This is the belief that drives offenders to brutally torture and kill another person suspected of sorcery. Even persons as young as 16 years are convicted of such offences because they are brought up and raised with this belief of sorcery and the harm it inflicts on another person and the community as a whole. ${ }^{7}$ The following are quotes taken from judgments and sentencing decisions of persons being dealt with for wilful murder related to sorcery killings:

In his sleep he had a dream. In that dream he saw the deceased [suspected sorcerer] come and carve out his son's eye with a knife. Shortly afterwards, the son developed swelling of his eye and died as a result of that swelling. ${ }^{8}$

5 Public Prosecutor v. Apava Keru and Aia Moroi [1985] PNGLR 78 at 80-1.

6 State v. Lota [2007] PGNC 167; N3183 (1 October 2007).

7 State $v$. Tayamina (Cr. No\# 302 of 2010) (10 May 2013).

8 State v. Gesie \& Guluwe [1980] PGNC 20; N254 (12 July 1980) at para 3. 
The whole community believed that the deceased was a reputed sorcerer who was responsible for the death of some 53 people in the village previously. The whole community resolved it was time to put an end to their suffering by eliminating the deceased and called upon willing and able members of the community to carry out the decision. ${ }^{9}$

A strong punitive and deterrent sentence is required to punish the offenders and to send a clear message to their community; who apparently seem to think that it's alright to kill a sorcerer or a reputed sorcerer for that matter; that it is wrong to kill another person including a sorcerer, reputed or not, and that they will be punished by the Courts, if they do. ${ }^{10}$

Data from the National Court cases showed that the victims of sorcery-related violence were skewed towards men: 17 victims were men and 3 were women. One inference that can be drawn from this data is that when a suspected sorcerer who is killed is a male, the matter is pursued in the courts. Few of the cases involve women being killed simply because when they are believed to be sorcerers the matter rarely comes to the court. This could possibly mean that the death of a woman may be less significant or may go unnoticed in the community or may not be seen to warrant an action taken against the offenders. However, one must also bear in mind that in many societies in PNG a woman leaves her people to marry into her husband's family and lives in his community with his relatives. In these instances a woman is on her own, and her relatives are not there to enquire or assist when a woman is attacked after being suspected of sorcery. Also, in other societies, especially those that are matrilineal, women are accorded much respect and therefore there are fewer cases of such atrocities being committed against women and reported.

However, in PNG there are almost daily reports of women being tortured, burned, slashed with knives, beaten with iron rods, and killed because they are suspected of practising sorcery or witchcraft. These cases often do not come to the courts, OPP or the police, which is why no action in the formal legal system is taken against the persons who commit these acts of violence. This is an issue that all stakeholders in law enforcement and community development must seek to address. Media awareness of the law and its effective and efficient implementation could be a start in addressing this issue.

\section{Geographical spread of sorcery cases}

The geographical spread of sorcery-related violence cases throughout PNG, from the recorded National Court cases, is shown in Figure 2.

9 State v. Yokum [2002] PGNC 24; N2337 (4 December 2002) at para 2.

10 State v. Siviri [2004] PNGLR 12 (30 August 2004) at para 8. 
13. Sorcery- and Witchcraft-Related Killings in Papua New Guinea

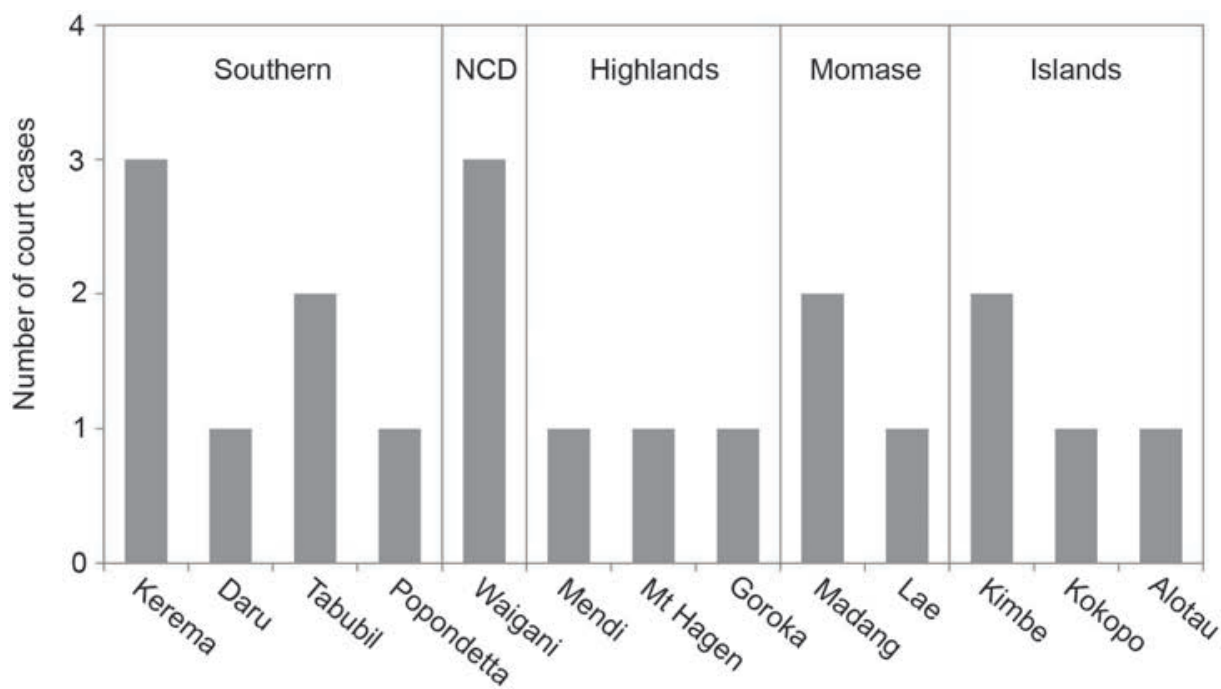

Court circuit areas

Figure 2: Geographical spread of sorcery-related violence cases in Papua New Guinea.

Note: NCD $=$ National Capital District.

Source: Pacific Islands Legal Information Institute databases (www.paclii.org).

We can see from Figure 2 that sorcery-related violence cases are more prevalent in the coastal regions (Southern, Momase and Islands regions) than in the Highlands Region. The other inference that may be drawn is that prosecutions for sorcery-related killings are more likely to commence in the coastal or island regions of the country and not in the highlands.

Finally, it should be noted that in referring to the above statistics of court circuit areas, the Waigani circuit area is a composite in that this circuit deals not only with matters of persons from the National Capital District, but also all other PNG ethnic groups that live in the city. For this reason the Waigani circuit area would be likely to cover more cases of sorcery and sorcery-related violence being an urban centre comprising many ethnic groups.

\section{Unexplained deaths}

The issue of sorcery-related violence ultimately goes back to the existence of the belief in sorcery. Most people in PNG believe in sorcery with it being like a religion with a supernatural aura. Often people use sorcery as an excuse. Sorcery is used to account for unexplained deaths and unnatural events (Gibbs 2009). 
When deaths occur it is often due to an illness, accident, or someone intentionally killing another person. The latter is done in instances of tribal warfare, retaliation or payback killing, or as a criminal act. However, when murder is not the cause of death, illness is a likely cause of unexplained death. Health facilities in PNG are not funded as they should be for illnesses to be treated properly.

Moreover, the lack of proper medical care in the country is apparent and the appalling state of its healthcare institutions gives rise to high mortality rates. One of the highest causes of death in the county is HIV/AIDS. This virus thrives in an infected person's body, resulting in imminent death. However, if access to proper health care is available for the infected person to get tested and treated then that person can live longer. Due to the lack of proper medical care this virus is causing many premature deaths of the working class in the country and thus is added to the average Papua New Guinean's mind as another unexplained death.

These unexplained deaths also result from fear of the unknown. People in the country do not all have access to good medical care for them to understand that a person looking sick and experiencing pain or other symptoms of an illness is basically just sick and requires medical attention. They are at times quick to point fingers and label it as an act of sorcery (Gibbs 2009:6).

Sometimes when deaths occur as accidents they are also held as acts of sorcery. In PNG the concept of accident is non-existent in that for every act there must be a possible reason, either physical or spiritual. For that reason often these deaths are not taken up in the courts of law, nor are enquiries made to ascertain the cause of the accident, but simply viewed as an act of sorcery because it occurred under supernatural or extraordinary circumstances. This habit of assumption has become a culture or norm in PNG society, with this largely attributable to a lack of understanding of health and medicine, fear of the unknown and the need for better health services to be provided to Papua New Guineans.

\section{Recent amendments to the Criminal Code}

On 28 May 2013 the PNG government enacted legislation amending the existing laws in the Criminal Code. These amendments were largely done in relation to the penalties to be imposed for wilful murder, rape and other crimes of atrocious nature with aggravating circumstances. The new amendments contain a separate provision on sorcery-related wilful murder. This provision states that any person found guilty of murdering a suspected sorcerer is liable to the death penalty. This is the government's stand against sorcery-related killings and shows that such acts will not be tolerated. 
The OPP has usually treated sorcery-related killings as wilful murder and has charged accordingly, with the penalty for which the offender is liable to one of death. It awaits to be seen how, if at all, the recent amendments will impact on the prosecution, court and formal legal system response to sorcery-related killings.

\section{Challenges for the criminal justice system}

In PNG there are already laws in place that provide for acts of sorcery and sorcery-related violence. The laws in place do not in any way prevent law enforcement. Law enforcement can be utilised against persons responsible for acts of violence related to sorcery. For these reasons media and public awareness of these laws must be made. This all can be done, through proper funding and an increase in law enforcement capacity. In PNG the police are inadequately paid and infrastructure relating to their work needs either maintenance or restructure. With a police force in this situation, PNG cannot possibly contain sorcery-related violence, because the violence is usually a group attack and everyone in the community usually takes part. Police are often outnumbered and outgunned.

The other difficulty law enforcement faces is that of the costs and lengthy processes of the court. As explained earlier, the process to get a matter into court can be long, and at times witnesses move elsewhere and costs are incurred just to secure evidence before the court. This should not be the case, if our courts and law enforcers had adequate capacity and funding to deal with these cases. Costs can also be incurred by the investigations; these include medical bills, transport, and phone bills. Therefore, the way to justice is long and quite costly.

One of the fundamental things lacking in PNG is interagency communication between stakeholder groups. Stakeholder agencies such as law enforcers and other agencies, including non-government organisations, need to better communicate, in a coordinated way, to tell the public what their offices do and that there is help for those who have been victims of sorcery-related violence or that persons suspected of sorcery can be dealt with by law. Awareness is a key factor.

\section{Conclusion}

There are laws already in place that make unlawful acts of sorcery and witchcraft-related violence. It is up to PNG and its people to utilise these laws and involve law enforcers to have justice administered. This case analysis has 
shown that sorcery and the belief in it is indeed something the criminal justice system recognises and PNG's laws have been created to provide for this and to address the matter of sorcery-related violence. However, analysis of the data show that there are not many cases before the criminal courts of sorcery-related killings and even fewer of persons accused of practising sorcery. One possible explanation for this is the act of sorcery-related violence is perceived by the entire community as being an act of elimination of suffering and evil in their communities.

Another insight from the data is that where a woman is suspected of being a sorcerer and is subjected to acts of torture, violence or even death, these matters are rarely brought to court or followed up in any investigations to result in legal proceedings. This unfortunately is consistent with the widely held view that women are less influential in the PNG community than men.

There are evident challenges for law enforcement agencies, educators, health and caregiver agencies, and the country of PNG as a whole. It is undoubtedly people's lack of understanding and fear of the unknown that has made deaths of known or suspected sorcerers to be insignificant. Although sorcery-related violence may seem understandable in the PNG context, the international community views it as heinous, and PNG must realise that such deaths cannot be overlooked. To address this serious issue PNG must act now to maintain interagency communications, to attain appropriate funding for infrastructure and capacity building, and also work with the community to respect the culture but also instil knowledge and understanding of the laws and the appropriate actions to take. The people must know that these services are here and that offenders of the law can, and will, be dealt with by the courts of this land.

\section{References}

Constitutional and Law Reform Commission of Papua New Guinea 2011. CLRC Reference No. 7: Review of the Law on Sorcery and Sorcery Related Killings.

Gibbs, P. 2009. Sorcery and AIDS in Simbu, East Sepik, and Enga Provinces. Occasional Paper No. 2. Boroko: The National Research Institute.

Oxfam 2010. Oxfam Studies on Violence \& Insecurity in the Southern Highlands, Simbu, and Eastern Highlands Province. Draft paper, International PNG Highlands Program.

Rangan, J. 2009. Sorcery in Kokopo. Office of Public Prosecutor and New Guinea Islands Regional Office. 


\section{Sorcery-related violence court cases, 1980-2012}

Acting Public Prosecutorv. Uname Aumane [1980] PNGLR 510

State v. Gesie \& Guluwe [1980] PGNC 20; N254 (12 July 1980)

State v. Karavea \& Karavea [1983] N452(M) (20 September 1983)

State v. Kwayawako [1988] PNGLR 174

Kwayawako v. State [1990] PNGLR 6 (30 November 1989)

Roger Jumbo and Aidan Awatan v. State (1997) SC516

State v. Arnold [1997] N1658 (21 November 1997)

State v. Sambura [2002] PGNC 114; N2219 (18 April 2002)

State v. Yokum [2002] PGNC 24; N2337 (4 December 2002)

State v. Baipu [2003] PGNC 59; N2451 (30 July 2003)

State v. Siviri [2004] PNGLR 12 (30 August 2004)

State v. N'Danabet [2004] PGNC 56; N2728 (9 November 2004)

State v. Binape [2004] PGNC 57; N2727 (12 November 2004)

State v. Visari [2006] PGNC 61 (15 June 2006)

State v. Jackson [2006] PGNC 154; N3237 (24 October 2006)

State v. Mohavila [2006] PGNC 106; N3385 (25 October 2006)

Irai Thomas v. State SCR 8 of 2006 Unreported SC Judgment dated 26 Feb, 29 August 2007

State v. Miritok [2007] PGNC 164; N3466

State v. Lota [2007] PGNC 167; N3183 (1 October 2007)

State v. Parara [2008] PGNC 259; N3957 (22 February 2008)

State v. Martin [2008] PGNC 29; N3312 (12 March 2008)

State v. Wapsi [2009] PGNC 84; N3695 (24 July 2009)

State v. Mathias [2011] PGNC 228; N4670 (9 September 2011)

State v. Niruk [2012] PGNC 152; N4821 (3 October 2012)

State v. Tayamina (Cr. No\# 302 of 2010) (10 May 2013) 
This text is taken from Talking it Through: Responses to Sorcery and Witchcraft Beliefs and Practices in Melanesia, edited by Miranda Forsyth and Richard Eves, published 2015 by ANU Press, The Australian National University, Canberra, Australia. 